\title{
Law Enforcement, Education Accessibility and The Kanun
}

\author{
Indrit Vucaj \\ Oklahoma State University
}

\section{Doi:10.5901/mjss.2015.v6n1p419}

Abstract

This study exposes the violation of Articles One through Five in The Universal Declaration of Human Rights compiled in Paris on December 10th, 1948 by the people of Albania, the lack of law enforcement by official authorities and the deprivation to formal educational programs. "The Kanun," provides the grounds upon which Albanian culture is based (Littlewood, 2002), contains the set of ideas that regulates Albanian blood feuds (Grutzpalk, 2002) and defines in a broad sense the sets of norms and rules of social activities based on very specific notions such as honor, loyal, trust, belief, assurance for safety and truce incorporated in the Albanian society (Celik \& Shkreli, 2010). The study is built upon Cosmopolitan framework and to defense of Universal Human Rights. The legal system is examined into three historical periods: one, from fifteenth century, time Kanun was written to around 1946 when dictatorship regime was established; two, Communist regime from around 1946 to 1992 and three, from 1992 to present. The study will describe how legal system has responded at different historical times to blood feuds and analyze how lack of law enforcement has helped perpetuate the problems since the fifteenth century. Education perspective will be theoretically reframed in terms of accessibility and comprehension and ability to interpret Kanun. Individual knowledge capabilities, where Kanun is most practiced will be studied to explore the differences between urban and rural areas and how each differentiates and contributes to phenomenon.

Keywords: Albania, kanun, law enforcement, education accessibility, cosmopolitanism, human rights

\section{Law Enforcement, Education Accessibility and The Kanun}

Albania, relatively homogenous [country] ethnically (Schwandner, 1996; Cava \& Nanetti, 2000; Bishku, 2013), is a country larger than the state of Maryland with a strategic importance the size of China (McClear, 2001) and also a poor country, the poorest in Europe (Bajrovic \& Satter, 2014; Rieff, 1997; Littlewood, 2002; Binder, 2008; Schmidt-Neke, 2007).

The Albanians have always been prone and vulnerable to problems of poverty and isolation from the world, especially in the rural areas (Cava \& Nanetti, 2000). Throughout history, Albanians were unjustly given a gloomy repuation for its cultural blood feuds phenomenon. "Mysterious Country," "Land of Miracles," "Unknown Albania," "Darker than dark Africa" are only few whimsical names that are given to Albania, the country which is inhabited by the oldest people in Southeastern Europe (Chekrezi C. , 1919). Considerable attention has been given to many exotic pecularites associated with Albania (Saltmarshe, 1999). These include sworn virgins who assume male societal roles (Young, 2000), the ancient Albanian legal and moral code, the Kanun of Lek Dukagjinit (Arsovska, Understanding a 'Culture of Violence and Crime': the Kanun of Lek Dukagjini and the Rise of the Albanian Sexual-Slavery Rackerts, 2006) and the blood feuds (Saltmarshe, 1999).

Kanuni i Lek Dukagjinit, a "code based on the concepts of honor and blood" (Schwandner, 1996; p. 7), provides the grounds upon which Albanian culture is based (Littlewood, 2002) and contains the set of ideas [doctrines] that regulates Albanian blood feuds (Grutzplak, 2002), administrated and modified justice [in Albania] for 500 years referring to the territorial ruler, Lek Dukagjini (Schwandner, 1996). Dating from the $15^{\text {th }}$ century, the customary common law called the Kanun (Gjecovi, 1989) codified norms that were heavily influenced by Islam and Catholicism (Del Re, 1995). According to the ancient code tradition, still observed today (Rainer, 2012), "blood should be always be avenged by blood" (Thompson, 2003; p. 11). However, the Kanun does not only require retribution by blood. Compensation is taken as an alternative method of dispute and resolution (Tokareva-Parker, 2004).

\section{Research Purpose}

The purpose of this paper is not to trace back the roots of revenge but rather to expose the violation of Articles One through Five in The Universal Declaration of Human Rights as compiled in Paris on December 10 19 , 1948 (UN General 
Assembly, 2014) and contrast the changes and the effectiveness of the legal system and the education availability and accessibility in three different historical periods.

Additionally, throughout the analysis of three different periods of time, it will be observed and noticed how the use of Kanun in society was altered in response to differences that the legal and education systems provided at three different historical parts and understand whether law enforcement and/or education system has helped perpetuate the problems with the use of the Kanun since the $15^{\text {th }}$ century, the time when Albania was occupied by the Ottoman Empire (Bishku, 2013).

\section{Research Introduction}

Albania has largely been known throughout the world for its eminence of revenge, with the blood feuds being the dominating [and regulating] factor of many remote mountain communities' social life (Pettifer, 1994). Ducros (1926 cited in Grutzpalk, 2002) regards blood feuds an ancient European legal problem; however, vendetta offered interest to social scientist who could frame an alternate perspective on modern legal system and their presumed development. Accordingly, Triantafilou (2005) argues that revenge in Albania is a social mechanism that preludes legal systems. Congruently, the people of Albania are not necessarily fond on the practice of the Albania but society plays a determining roles in the practice of the Kanun and in the eyes of the public.

Public education has continually changed and adapted to each each political system in place. Some ruling governments has placed a higher priority than the others. Consequently, its importance has been increased or decreased based on the effort put forth by the each governing body. That said, the changes attributed to the education have had a deep impact on the lives of Albanians. Although scholastic attempts have been made to bring this issue to light earlier in time, unfortunately scholars have narrowed their concers of the legal life in modern Western societies (Black, 2003).

This paper does not focus on differences between modern Western societies and Albania. The paper focuses on laying out a picture of different legal systems throughout the history of Albania from $15^{\text {th }}$ century to present and it is aided with changes in the eduational system.

\section{Literature Review}

There have been many definitions pertaining to Kanun and its' regulatory mode. The Kanun is a common legal and moral code has closely united Albanians (Schwegler \& Smith, 2012). Erich Fromm (1973) defines Kanun as "a spotenaious form of aggression (p. 272)"unlike other scholars (Fox, 1989 cited in Arsovka \& Verduyn, 2007; McClear, 2001; Schwegler \& Smith, 2012) who consider Kanun's primarily focus on the principle of honor [nderi], hospitaliy [mikpritja] and word of honor [besa]. Chekrezi (1919) addresses besa, which simply means "good faith", a peculiar institutional acceptance of the country and McClear (2001) believes that besa or the honor of promising your word "goes beyond the grave (p. 21)." If an Albanian gives you besen you know that it can be counted upon (McClear, 2001).

The works of Max Weber and Emile Durkheim go beyond the question whether blood feuds cause social order or disorder. They depict and argue that it has to do with social order in non-modern societies (Grutzplak, 2002). In the eyes of the "Princess of Albanian Highlands," Emile Durkheim (Chekrezi C. A., 1919, p. v), vendetta, a family blood-feud according to Oxford English Dictionary (2014), is one of the many manifestations of personal bonding between members of a mechanical solidarity group. Blood feuds are considered a passionant and coarse reaction against an external threat that distinguishes members and aliens.

Blood feuds are not real sanctions as portrayed by individuals (Grutzplak, 2002) but a form of agression different form normal defensive aggression in two different ways: (a) it is an act performed in cold blood after the event has occurred and therefore, not a defense against immediate and imminent danger and (b) it is of great intensity often crude, vicious and insatiable (Fromm, 1973). To Frijda (1994 cited in Gower, 2012) revenge is the act designed to harm someone or a group to repair the harm, to stop it from occuring or continuing in the immediate confrontation or to produce material gain. It is argued (Triantafilou, 2005) that revenge of harming someone is associated with societal norms, usually considered revenge and like most other norms, they are probably acquired and not inherited. Western societies regard violence and crime as immoral, illegal and illegitimate (Arsovska \& Verduyn, 2008). The wish to avenge is a considered a leftover of an archaic epoch (Waldmann, 2001; p. 435) and modern conceptions attribute the resposibility of prosecuting cirminals to criminal justice authorities (Arsovska \& Verduyn, 2008). 


\section{Framework/Conceptualization}

\subsection{Cosmopolitanism}

This study will seek to analyze cosmopolitanism from the lenses of moral cosmopolitanism and institutional cosmopolitanism. Moral cosmopolitanism, according to Brown and Held (2010), is the corresponding duties of global justice, the guardianship of human rights and the reformation of international unjust systems to align with cosmopolitan philosophies and values. Beitz (1994 cited in Brown \& Held, 2010) describes institutional cosmopolitanism with focus on examining institutional designs implementation for normative considerations. Beitz (1994 cited in Brown \& Held, 2010) suggests that institutional cosmopolitanism "holds that the world's political structure should be reshaped so that states and other political units are brought under the authority of supranational agencies of some kind (p. 124). Although the study will take into considerations Immanuel Kant's ideologies of cosmopolitanism, it is noteworthy to illustrate that Kant was not the first scholar to present cosmopolitan ideas (Brown \& Held, 2010). More specifically, from Kant's influential essay Perpetual Peace, later turned into a philosophical book conveying and arguing a prominent message of ius comopoliticum (cosmopolitan right/law) synthesis, I withdraw assumptions on the state of peace (have the right to be legally protected by a legal code system in general) to be established and institute a morally and affirmatively sense of social justice (formation of institutionalized agencies geared towards individual well-being and assurance of social control).

\subsection{Moral Cosmopolitanism}

Moral cosmopolitanism, according to Jones (2010), "affirms the equal moral worth of each individual person, regardless of sex, race, ethnicity, religion, nationality, or any other form of group membership beneath the level of the class of all human beings (p. 116)." On the contrast, Kanuni i Leke Dukagjinit encourages and fosters the blood revenge regardless of equal and moral worth of each individual. One of the main principles that the Kanun focuses on is honor [nderi] (Schwandner, 1996; Fox, 1989 cited in Arsovka \& Verduyn, 2007; McClear, 2001; Schwegler \& Smith, 2012). Sommers (2009) argues that honor cultures focus less on the whole concept of responsibility and particularly the "deservingness ( $p$. 42)" of the offender. In fact, individuals in honor cultures often believe they have a sacred duty to avenge the offense with one that may have nothing to do with any consequentialist considerations (Sommers, 2009). The problem with honor cultures though is that the Albanian perception suggest honor as a commodity to be defended by a group as a whole, rather than an individual alone (Tokareva-Parker, 2004). Although this seems to have a positive communal effect within a given group, I find it disturbing to involve others that have no connection to the feuds themselves. Just like Celik and Shkreli (2010) attest that issues might also spread to family members who are not initially involved (Celik \& Shkreli, 2010). The thought of avenging because of honor is in contradiction with the view of moral cosmopolitanism where each individual of human race is accepted and nurtured with a shared acceptance and morality.

\subsection{Institutional Cosmopolitanism}

If correct, institutional cosmopolitanism unifying anyone who participates in an institutional framework in which human rights are violated negatively and to reframe from harming . More specifically, according to Pogge (2003 as cited in Nees, 2010), institutional cosmopolitanism generates moral responsibilities. According to the ancient Albanian legal and moral code, the Kanun of Leke Dukagjinit (Arsovska, 2006) surpasses and preludes the legal [institutionalized] system (Triantafilou, 2005) and traditionally took precedence over state or church law (Littlewood, 2002). I argue that it is almost impossible to institute an institutional cosmopolitanism state when there is an existent violation of basic universal human rights and institutionalized cosmopolitanist agency has a duty and a moral obligation to exist for the benefit of the shared universal morality. For this reason, institutional agencies will be examined from the lenses of reactivity towards the phenomenon.

\subsection{Universal Declaration of Human Rights}

The Universal Declaration of Human Rights was adopted by the UN General Assembly on December 10th 1948 . The human rights declaration came as a result of World War II experience with the purpose of unifying nations and the international community to vow to never again allow similar atrocities arising from conflict happen again (UN General Assembly, 2014). 
With that in mind, the General Assembly constituted thirty articles pertaining to the defense of human rights. This paper takes into consideration only five first articles of The Declaration of Human Rights that Kanun violates since people often associate the Kanun with the ancient and tarnished as the rules to revenge in blood feuds (Arsovska, 2006). More specifically, five first articles are depicted verbatim from the United Nations General Assembly (2014) as following:

\subsubsection{Article 1.}

All human beings are born free and equal in dignity and rights. They are endowed with reason and conscience and should act towards one another in a spirit of brotherhood.

\subsubsection{Article 2.}

Everyone is entitled to all the rights and freedoms set forth in this Declaration, without distinction of any kind, such as race, colour, sex, language, religion, political or other opinion, national or social origin, property, birth or other status. Furthermore, no distinction shall be made on the basis of the political, jurisdictional or international status of the country or territory to which a person belongs, whether it be independent, trust, non-self-governing or under any other limitation of sovereignty.

\subsubsection{Article 3.}

Everyone has the right to life, liberty and security of person.

\subsubsection{Article 4.}

No one shall be held in slavery or servitude; slavery and the slave trade shall be prohibited in all their forms.

\subsubsection{Article 5.}

No one shall be subjected to torture or to cruel, inhuman or degrading treatment or punishment.

\section{Methodology}

First historical period dates from the $15^{\text {th }}$ century since creation of the Kanun (Del Re, 1995) to around 1944 the Communists took over Albania and Communism regime was established in Albania (Zickel \& Iwaskiw, 1992). Second historical period pertains from around 1944 to 1991, the time Communism demised under Ramiz Alia's authority two years after the tearing down of the Berlin Wall (Cava \& Nanetti, 2000; Bajrovic \& Satter, 2014). And, third historical period correspond from 1992 to present known otherwise known as post-communism (Lerch, 2013) and since Albania joined Council of Europe soon thereafter, a time whose aim is "to create a common democratic and legal area throughout the whole continent [of Europe], ensuring respect for its fundamental values: human rights, democracy and the rule of law (The Council of Europe, 2014)."

\section{Legal System}

Research shows that norms of revenge have the tendency to flourish and become more robust in societies where the influence of legal institutions and central authority is weak (Triantafilou, 2005). Formalized as the oral laws in the $15^{\text {th }}$ century (Pancevski \& Hoxha, 2007 cited in Gower, 2013) and officially collected together with $20^{\text {th }}$-century revisions (Gjecov, 1989), Kanuni i Leke Dukagjinit in northern Albania draws revenge norms that still predominantly control societal behavior (Triantafilou, 2005).

Today, the Kanun survives in Northern parts of Albania where the Turkish Goverment never exercised real authority. In fact, ethnically or racially, the Albanians have never been affected in any way by their submission to the Ottoman Empire's rule. This has happened because the despised Turks have been utterly incapable of influencing or changing the course of Albanians' national characteristics, language, customs and traditions. Yet, they did exercise a portentous influence in many other directions (Chekrezi C. A., 1919).

Revenge [in blood feuds] is characterized as a mechanism of social control and the maintenace of the balance of 
power between medium-sized groups that were not under the control of formal authority (Waldmann, 2001) but modern scholars (Aijmer \& Abbinik, 2000; Messner \& Rosenfeld, 2001; Arsovska \& Craig, 2006) strongly emphasize the responsibility on the centralized and institutionalized crimininal justice system authorities to prosecute criminals [although they may associate with blood feuds] since the forbidding of "self-help" is deeply rooted in the Western value system (Arsovska \& Verduyn, 2008). For this reason, Rieff (1997) argues that to most people in Britain, France or Germany, the words Albania and Europe are an improbable fit. An examination of each historical period seen from the lenses of the legal system is the following.

\subsection{Historical Period 1}

From the $15^{\text {th }}$ century to 1912 , Ottomans dominated Albania and from 1912 to around 1944 , once President Zogu, later to be self-proclaimed King Zogu ruled the country. Although two types of rulings and rulers existed during this period, this study takes the whole into once examination since both rulings had similar responses to the Kanun.

Storytelling suggest that Zogu's period is inapt to be studied seperately because of his irrelevant contributions to Albania, much less to the interpretation, intervention or interruption of the Kanun. King Zogu's efforts were and his focus had shifted more into personal power-consolidation to the point that many Albanians considered him a traitor who abandoned his country in the middle of the war. In fact, Caroll Binder who had the opportunity to visit Albania in 1930 by car from Greece ridiculed Zogu's monarchy by stating "This funny little kingdom [of Zogu] is about five hundred years behind the rest of Europe (Binder, 2008; p. 64)."

During Ottoman Empire raid in the Balkans, most of Albania was conquered and the remaining northern Albanian lords were forced in vassalages (Hupchick \& Cox, 2001). While turned in vassalages, Albanian lords in the northern part paid a tribute to self-govern within Islamic laws of the Ottoman Empire. It was during this time in the $15^{\text {th }}$ century that the Kanuni i Leke Dukagjinit was created. The Kanun was created to self-govern from within separately from the Islamic law composed universally in the Balkans and wherever Ottomans conquested. As such, it is presumed that the creation of the Kanun played a vital and necessary role in the governance of northern Albanians. When the Kanun was created in northern Albania there were only two codes, Islamic laws compiled in the Koran and the Kanun compiled by Lek Dukagjini, one of the northern Albanian lords. Therefore, I argue that the Kanun at the time of its creation was a necessary initiative to regulate the lives of self-governing Albanian in absence of universal applicable rules and laws by any type of state authority which in this case were Ottomans.

Examining the issue from a cosmopolitanist perspective, thus the Kanun aligned perfectly well with moral and institutional cosmopolitanism ideologies. In other words, the Kanun aligned perfectly well with affirmation of moral worth for each individual subject because it comprehensively covered each sphere of lives including any type of quarrels and not only the blood feuds. Similarly, the Kanun institutionally restored equal order among fellow Albnaians in times of confused disturbance until liberation from the Turks in 1912. Thus, it is valid to conclude that during this time the Kanun was a proper code to develop and an important tool to use in absence of another formal authority presiding over its ruling.

\subsection{Historical Period 2}

During this historical period, the rights of the Albanians were extensively guaranteed (Malcolm, 1998). Under Enver Hoxha's (country's first and the only Communist leader) regime, the defense of the family's honor was strictly prohibited. Any such practice of ancient customs was severely punished; murderers were trialed to death and their families were isolated with limited access to basic supplies and society (Jolis, 1997 cited in Arsovska \& Verduyn, 2008).

This period also coincides with the compilation of the the Universal Declaration of Human Rights. It is yet unknown, due to lack of research, misinformation and/or isolation at the time events occurred, whether Albania's former Comunist leader, Enver Hoxha, deliberately enforced the codified law system due to reasons related to observance and veneration to the Universal Declaration of Human Rights or he simply attempted to restore total and absolute controlled order within the country's boundaries. Whether by design or coincidence, the period of Communism in Albania ensured and strenghtened human rights as defined by the the Universal Declaration of the Human Rights and fostered a morally- and institutionally-perceived accepted form of governance whose focus was equality, well-being and safety-assurance for the citizens of Albania. Cooperatives were created and they ensured a sense of commonness. Material gains were distributed fairly, equally and consistently. Institutional agencies aimed to serve the people and to provide better communal working conditions. In every aspect, this period took an extensive role in ensureness of equality of the human capital. 


\subsection{Historical Period 3}

After the downfall of Communism, according to Waldmann (2001), there was a decline of state authority and an upward revaluation of the Kanun. More specifically, the inability of the judiciary and state authority to enforce the laws and regulations had emerged, according to Cava and Nanetti (2000) a new group of young men at risk of criminal behavior. Such emerging themes is not, per se, a violation of human rights but it is indeed a non-existent approach of moral cosmopolitanism (failure to acknowledge each individual's moral worth and contribution to commonal society) due to lack of life opportunities and failed institutional cosmopolitanist perspective (inability to interverne and intersect problematic sectors). Of course, the argument here is not Albania's central state authority unwillingness to intervene but rather the demise of the institutions after about five decades of communist oppression brought dismays in implementation of revenge norms (Triantafilou, 2005). Although there have passed more than two decades since the demise of formal institutions, the enforcement of legal authority is still weak and almost non-existent in relation to the Kanun. A good proof of that are the daily killings and isoltion into one's homes without access to freedom, liberty or tos upply for basic family needs.

\section{Education Accessibility}

Kanuni i Leke Dukagjinit has very distinctive and unique features applicable to Albanian society. However, its role is elusive, mostly unknown and quite misunderstood (Arsovska, 2006; Tokareva-Parker, 2004 ). For years, Albanian have been isolated without access to education, which makes an even more terrifying situation (Arsovska \& Verduyn, 2008). Kanun's 1263 articles are much more than the regulation of the rules of blood feuds in the lives of mountaneious Albanians (Arsovska, 2006). But in order to find out in more depth about the education accessability and the capability to interpret the Kanun, it is anticipated, in general, to hypothesize that older Gheghs (Albania contains two subcultures, Ghegh/Tosk; Gheghs - subculture found in northern Albania where the Kanun is most prevalent) from rural areas (where the Kanuns is more predominant) would have a better understanding of the Kanun (Arsovska \& Verduyn, 2008). On the contrary, younger and less educated, who only know the laws of the Kanun artificially are inclined to justify various types of crimes with the use of the Kanun laws as a shield (Arsovksa \& Verduyn, 2008). Reinterpretations of the Kanun put in question the respect for international recognition of the human rights and the rule of law itself (Valinas \& Arsovska, 2008). Three historical periods are examined individually as following.

\subsection{Historical Period 1}

Majority of the Albanians lived in villages and never had access to education. The minority that were able to attend education were amended by the Royal Constitution which made the education of the citizens of Albanian an exclusive right of the state. Mainly that occurred due to the non-existence of schools using the Albanian language since the Ottomans forbid the use of Albanian language in schools (Zickel \& Iwaskiw, 1992). However, for a short period of time (about ten years) the Italians had controlled Albanian education (Hanbury-Tenison, 2009).

During this time, there was a distinct value on education, especially from urban populations who were heavily recruited for the military and the bureaucracy (Hupchick \& Cox, 2001) but the Albanian nation state was too instable and weak to contribute and establish an education system (Schmidt-Neke, 2007).

While I examine the issue from the lenses of human rights, it is my belief that there is no violation of the human rights because for one, human rights were't foundationally constituted nor were they existent and two, the Kanun was a widely accepted form of governance. From a cosmopolitanist perspective, in my readings, I find many failed institutionalized cosmopolitan initiatives to offer the opportunity to educate to every citizen of Albania although several attempts were undertaken.

Morally speaking, I find moral cosmopolitanism approach of the Albanians faulting the system set forth by the Ottoman Empire similarly as an attempted excuse for the illiteracy and the inability of the Albanians to read and write, much less interpret the Kanun and how it governed their lives. Institutionally speaking, the departure of King Zogu from Albania to live in exile and his failed educational reforms are clear evidence of failure by the central authority to engender moral and national responsibility and commitment in regards to educating every Albanian citizen.

\subsection{Historical Period 2}

This historical periods pertains to the time that Albania was under the rule of the Communist leader, Enver Hoxha to post- 
communism in 1991. During his time in regime, Hoxha described the bood feuds as a legacy of feudalism. Although Albania organized its education system to reflect communist ideologies, like many other Communist states, education in Albania had its own unique educational system style and it was at a high state priority (Holmes, 2009; Zicker \& Iwaskiw, 1992).

Albania was a believer in Marxism ideology and as such, most of the services including education, were offered free of charge (Holmes, 2009; Ebon, 1948) and it required to educate all children of all social classes [including children coming from families caught up in blood feuds] including the illiterate peasants in remote areas [where Kanun mostly predominated] (Zickel \& Iwaskiw, 1992). As of late 1946 about 85 percent of Albanians were illiterate and it is estimaed that by 1980s illiteracy had been virtually eliminated. Mountainoues districts reached as high as 97 to 98 percent of illiteracy rates with the exception of clerics who were the only ones able to read and write (Schmidt-Neke, 2007). From the above studies, it appears that there is an abidance and commitment of the Communist regime to human rights enacted shortly after the regime laid its foundation in Albania. Similarly, Communism affirmatively and equally gave the opportunity to each citizen of Albania to attend education programs regardless their remote, rural or urban location. Thus, it is possible but not affirmatively certain that during this time due to educational programs, Albanians may have reshaped a different thought process towards blood feuds. Institutional approach was swift, smooth and high whereas teachers in remote, rural or urban areas were expected to carry on the responsiblities of a teacher whose commitment was to educate virtually every Albanian.

\subsection{Historical Period 3}

After 1991majority of the teachers relocated from rural areas [where Kanun was most applicable] to urban areas leaving schools understaffed and/or abandoned (Zickel \& Iwaskiw, 1992). The surge of revenge killings after Communism (Waldmann, 2001) may be attributed to the decline of the state authority. Nonetheless, the compiling elements of the Kanun which were forgotten, degraded and mostly used for "self-defense (p. 440)" had seriously affected the traditional practice of the Kanun (Waldmann, 2001). In other words, the inability to interpret the the doctrines of the Kanun as they were initially intended has shifted towards a wrongful use with the tendency to cover various crimes even by organized crimes organizations (Arsovksa \& Craig, 2006; Mortimer \& Toader, 2005 cited in Arsovksa \& Craig, 2008; Waldmann, 2001).

Rural children (where the Kanun is most prominent) are socially exclusive due to their lack of education (Cava \& Nanetti, 2000). A study from World Bank (2000), identified the youth at risk of abanding school. Such droppings out of school has increased the risk of social exclusion and have resurge illiteracy level. Most of these drop outs occur due to lack of confidence in the Albanian educaiton system (Cava \& Nanetti, 2000). Thus, I argue that in this historical period moral cosmopolitanims is fully ignored and state authority has not only failed to take an institutional cosmopolitan perspective to protect its citizens but also has not taken into consideration of any valid reformative acts to spark interest in the Albanian education system to increase current or offer new incentives to attend educational programs with the purpose of terminating blood feuds and the practice of the Kanun.

\section{Findings}

Although the findings in this paper may not be generalized in terms of cause-effect, it is my opinion to contribute the cause (lack of education) to the effect (practice of the Kanun). But in order to understand this generalization is it important to learn its significance. Revenge is not simply a way of dealing with blood feuds. It is much more than that (Arsovska, 2006). Laura Blumenfeld chronicled and embedded her perception on Albanian revenge based on the concept of kinship whereas she argues that "revenge is not a choice but a sacred duty (p. 1)" tied to family loyalty (Johnson, 2002).

Legally speaking, according to the Albanian code tradition "blood should always be avenged by blood" (Thompson, 2003; p. 11) and from fifteenth century to Communist regime establishment such form of governance was understandably accepted albeit a legal Islamic code imposed by the Ottoman Empire governed majority of the country, except the northern Albania.

So far, there is no indication of violation of human rights. On the contrary, it appears that the customary code was generated to protect the rights and the well-being of northern Albanians. Although created over 500 years ago, the modernity of the code is quite misunderstood. For example, compensation was an alternative method of dispute resolution (Tokareva-Parker, 2004) but I find it quite acceptable to assume that high illiteracy rates (Schmidt-Neke, 2007) and the inability to interpret the Kanun properly might have caused a surge in blood feuds. From a cosmopolitanist perspective, I find the Kanun aligned with the principles of Cosmopolitanism since the purpose of the Kanun was to 
assure the rights of each citizen and to properly trial any wrongdoing that would violate the lives of the northern Albanians.

In my opinion, it is safe to assume that the Kanun's (institutionalized binding legal code agency for the northern Albanians) primary purpose was to affirm equality, moral worth and acceptance within the community it governed. As it pertains to rights to education, no major roles were assumed to contribute to society it governed. However, that should not be misunderstood as a sign of violation between individual subjects. Part of it is because the Kanun did not specify and/or discriminate between gender, class or social status. It simply was applied across border to each individual. The other part is that the Kanun sought to regulate the lives of Albanians in its entirety broadly and it did not surgically focus on a certain sphere of life. Thus, I conclude that even though the Kanun did not emancipate Albanians educationally, during first historical period, it did maintain law and order among northern Albanians and ensured equity among subjects, peace among two governing bodies and reverence towards honor, hospitality and word of mouth.

Although shorter in time, second historical period had more of an impact in the lives of the Albanians than did the first historical period. During this time, there was an upwelling in literacy levels (Schmidt-Neke, 2007) and a sharp decline in blood feuds because of fears of isolation and prosecution from the Communist legal code system (Jolis, 1997 cited in Arsovska \& Verduyn, 2008). Communism offered the dignity that many Albanians that felt that it was lost before then. According to Schmidt-Neke (2007) education during this period contributed to "social integration and homogenization ( $p$. 13)." The social integration was unique and inclusive. This integration system allowed the peasantry in the remote areas (where the Kanun is most practiced) to gain access to education and blend with the emerging labor class.

Institutionally, the Albanian government put quite a bit of efforts to uphold education as accessible as possible to its citizens. Morally, the Communism encompassed ideologies of freedom and equality. Such encompassment is impeccably aligned with the human rights as portrayed in the Universal Declaration of the Human Rights. Communism upheld the dignity of the individual and assured the utmost respect for its citizens. Also, during this time quarrels in regards to blood feuds and any other type of social phenomenon were almost inexistent. The reason is very simple. Communist legal code condemned to death offenders or interned in remote villages individuals that were involved in any sort of disputes among one another. Private property was institutionalized, blood feuds were condemned, isolation was intact and people were assured treatment with dignity by the codified Communist law system.

Such enactment of legal system led to a temporary replacement of the Kanun. Thus, people were strictly prohibited to take revenge on any issues arising from any type of behavior. Note, I use the term temporary to suggest a comeback of the phenomenon as explained down further in this paper. The replacement of the Kanun and the enforcement of the Communist legal system brought an interesting issue in light. One of the doctrines in the Kanun suggested that a quarrel may initiate over land and/or personal property (Celik \& Shkreli, 2010). That said, in a Communist regime, the possession of a private property was not permitted. So, it is also possible to conclude that quarrels ceased existing because there was no source for them to start in the first place. And if they did somehow, the legal system brutally oppressed them.

Third historical period is, in itself, transformative for many reasons. The uprisings of 1990-1991 brought many negative changes to society. Among destruction of state authority institutions, demonstrators also ruined and devastated educational institutions. Education in Albania was not anywhere to be vowed until 1995. On June 21th, 1995 a new act regulating the primary and secondary school system was passed (Schmidt-Neke, 2007). Although an act on defense to educational programs was passed, its financing was depended on foreign aid. This move sent pupils and students away from attendance of formal education because of their inability to pay. Thus, the literacy rates declined. More specifically, compared to its ex-communist peers, Albania scored the lowest in value of education and the highest in disciplined behavior (Schmidt-Neke, 2007). The problem with disciplined behavior is that it does not result in good performance but it rather replaces it. Rural schools (where the Kanun is most predominant) in Albania are capable of discipline-enforcement but unable to encourage students and pupils to learn (Schmidt-Neke, 2007).

From a moral Cosmopolitanist perspective, although each Albanian was by law entitled to education, it was not practical for every Albanian to attend educational programs due to lack of financial means, lack of infrastructure (Triantafilou, 2005) and unsuitability of structural environments such as health hazard conditions lacking heating systems, water supply and sanitary facilities (Schmidt-Neke, 2007). From an institutional Cosmopolitanist perspective, the failure [of the government] to maintain law and order affects schooling environments (Schmidt-Neke, 2007). Moreover, such failure, at times, isolates children and young female population due to fear of criminal offences. For example, numerous Albanian young women are not allowed by their parents to participate in extracurricular activities due to fear of kidnapping and enticement into prostitution (Schmidt-Neke, 2007).

Another reason why Albanian parents do not see worthwhile education system is because of their loss belief in the government and in the education system. Even Communist system is now distrusted and it is estimated that the rapid deterioration of education system could spur a growth in illiteracy levels and may return the country to its 1950s levels 
(Schmidt-Neke, 2007) which counted an 85 percent illiteracy rate in urban areas and almost 97 to 98 percent illiteracy rates in rural areas. This data suggest that there is a sharp decline in the interest of education. Coincidently, this sharp decline is accompanied by a growth of revenges in the old phenomenon of blood feuds. An estimated 10,000 blood feuds have surfaced in Albania since 1990s and around 1,600 families are in hiding to avoiding becoming victims (Cohen, 2012). Of course, such behavior is not only condemned and in violation with the Universal Declaration of the Human Rights but also not congruent with a Cosmopolitanist perspective whose shared morality is the accepted norm and behavior.

Throughout the study, I have discovered a pattern and a trajectory between educational attainment and the practice of the Kanun and more specifically the revenge in blood feuds. Although there may be other contributing factors that alter the outcome of a cause-effect relationship, it appears that there is a pattern of negative relationship between education attainment and the practice of the Kanun. It is suggested that the higher educational attainment of the Albanians and the more comprehensive and higher priority the reforms in institutionalized policy-makers agencies, the less of the effect of the revenge in blood feuds. The opposite seems to hold true as well. Although the Kanun was initially created to maintain law and order among its citizens in the $15^{\text {th }}$ century, this ancient and medieval tradition should not exist in a modern society located at the heart of Europe.

\section{Discussion}

The evidence of customary blood feuds can be traced back to the sixth century A.D. and can also be compared to earlier Roman opinions (Tokareva-Parker, 2004) but it was not until the fifteenth century that northern Albanians formalized the Kanun which it also included the set of norms and rules that regulated blood feuds among many other social issues. Even though blood feuds can be traced back to Roman, Chekrezi (1919) has concluded that the Roman power has not been of a significant influence to shape Albanian approach to blood feuds. Revenge usually encourages escalation of violence and, at times, it leads to blood feuds without end (Waldmann, 2001).

The problem with revenge does not lie solely on the act of the individual but also on the acts of the society. In Gregorovious' (1854) writings, whoever hesitates to revenge is ultimately the target whisperings and denigration of his relatives and the insults of strangers, who reproach him publicly for his cowardice (Sommers, 2009; Senechal, 1997 cited in Littlewood, 2002). The insults that relatives and the society throw are detrimental to one's self. In one way, they suggest a certain type of behavior (to be revengeful) and ignore other alternatives (mediation, compensation etc.). The issue with creating a certain behavior is concerning and yet, promising. I believe it is concerning because it forces one to do something one is not willing to abide by some ancient rule and simply do not want to get caught in the midst of medieval norms and modern laws. On the contrary, it is promising because studies (Picker, 1997) have rigorously shown that the effectiveness of informing community members with alternative norms creates a more efficient mode of behavior thus creating a more content and an acceptable behavior per a Cosmopolitanist perspective which is the acceptance of everyone within the human race without prejudices or dislikes.

This behavior can be altered by the generation of new contradicting norms or even better, the generation of competing norms (Triantafilou, 2005). Moreover, Traintafilou (2005) claims that such implementation assures that new norms can establish justice beyond the areas where state authority has no access due to distance, infrastructure etc.

Speaking from an educational perspective, the new political system in Albania seems to not have any contingent impact on educational standards (Schmidt-Neke, 2007). Of course, that creates even more problems because not only the new guiding principles ruling the country are not taken into consideration but also there is a tendency to ignore and consider any legal code worthless and unenforceable. The failure to maintain law and order affects schools greatly (Schmidt-Neke, 2007). At times, some schools do not seem to structurally comply with school standards. Few of them have security personnel employed (a practice happening for the first time ever in the history of Albania) and high walls are erected around the buildings. Normally, this behavior would not be acceptable in Western societies. For this reason, newer integration methodologies are crucial to integrating social phenomenon (the practice of the Kanun) to educational programs for the purpose of discontinuing such practice. Memushi (2003) is one of the few who has given substantial considerations but observers remain quite skeptical about the implementation of these ideas (Schmidt-Neke, 2007) and yet they fail to offer alternate action courses.

All in all, it is important for Albanians to realize that changes in institutionalized agencies, educationally and legally, towards the Kanun should not only relate to revenge killings in blood feuds but also to the theoretical and the actual modern emancipation of the ethnic Albanians (Arsovska, 2006). 


\section{References}

Aijmer, G., \& Abbink, J. (2000). Meanings of violence: a cross cultural perspective. Oxford: Berg.

Arsovska, J. (2006). Understanding a 'Culture of Violence and Crime': the Kanun of Lek Dukagjini and the Rise of the Albanian SexualSlavery Rackerts. European Journal of Crime, Criminal Law and Criminal Justice, 14(2), 161-184. Retrieved from http://content.ebscohost.com/pdf18_21/pdf/2006/GG1/01May06/21783277.pdf?T=P\&P=AN\&K=21783277\&S=R\&D=aph\&EbscoC ontent=dGJyMNLe80Sepq84y9f3OL̈CmrOyep7VSrqq4SrWWxWXS\&ContentCustomer=dGJyMPGnr1CvqbNluePfgeyx33vf2uOF $59 \mathrm{kA}$

Arsovska, J., \& Craig, M. (2006). "Honourable" Behaviour and the Conceptualisation of Violence in Ethnic-Based Organised Crime Groups: An Examination of the Albanian Kanun and the Code of the Chinese Triads. Global Crime, 7(2), 214-246. Retrieved from http://www.tandfonline.com/doi/pdf/10.1080/17440570601014479

Arsovska, J., \& Verduyn, P. (2008). Globalization, Conduct Norms and "Culture Conflict". The British Journal of Criminology, 48(2), 226246.

Bajrovic, I. C., \& Satter, J. R. (2014). Albania: From Bunkers to Ballots. Journal of Democracy, 25(1), 142-153. Retrieved from http://muse.jhu. edu/journals/journal_of_democracy/v025/25.1.bajrovic.pdf

Binder, D. (2008). Approaching Albania. Mediterrenean Quarterly, 19(1), 63-79. Retrieved from http://muse.jhu.edu.argo.library. okstate.edu/journals/mediterranean_quarterly/v019/19.1binder.pdf

Bishku, M. B. (2013). Albania and the Middle East. Meditettanean Quarterly, 24(2), 81-103.

Black, D. (2003). The Social Structure of Right and Wrong. San Diego: Academic Press.

Brown, G. W., \& Held, D. (2010). Editor's Introduction. In P. Press, G. W. Brown, \& D. Held (Eds.), The Cosmopolitanism Reader (pp. 114). Cambridge/Malden: Polity Press.

Cava, G. L., \& Nanetti, R. Y. (2000). Albania: Filling the Vulnerability Gap. World Bank Technical Paper. Washington: The International Bank for Reconstruction and Development/THE WORLD BANK. Retrieved from http://elibrary.worldbank.org.argo.library. okstate.edu/doi/pdf/10.1596/0-8213-4667-9

Celik, A. B., \& Shkreli, A. (2010). An Analysis of Reconciliatory Mediation in Northern Albania: The Role of Customary Mediators. Europe-Asia Studies, 885-914. Retrieved from http://ud4cl8nx8h.search.serialssolutions.com/?ctx_ver=Z39.88-2004\&ctx_enc= info\%3Aofi\%2Fenc\%3AUTF-8\&rff_id=info:sid/summon.serialssolutions.com\& rft_val_fmt=info:ofi/fmt:kev:mtx:journal\&rft.genre=article\&rft.atitle=An+Analysis+of+Reconciliatory+Mediation+i

Chekrezi, C. (1919). Albania Past and Present. New York: The Macmillan Company. Retrieved from http://hdl.handle.net/2027/uc2.ark:/ 13960/t77s7v216

Chekrezi, C. A. (1919). Albania Past and Present. (C. D. Hazen, Ed.) New York: The MacMillan Company. Retrieved from http://hdl.handle.net/2027/uc2.ark:/13960/t77s7v216

Cohen, N. S. (2012, July 30). Blood Feuds still boiling in Albania. Retrieved from USA Today: http://usatoday30.usatoday.com/ news/world/story/2012-07-29/albania-blood-feuds/56580022/1

DelRe, E. (1995). The Role of the Kanun, Common Law, in Changing Albania. Sociological Abstracts, 104-122.

Ebon, M. (1948). World Communism Today. New York/Toronto: Whittlesey House. Retrieved from http://babel.hathitrust.org/ cgi/pt?id=mdp.39015005275758;view=2up;seq=6

Fromm, E. (1973). The anatomy of human destructiveness. New York: Holt, Rinehardt and Winston.

Gjecovi, S. (1989). The Code of Leke Dukagjini. (L. Fox, Ed., \& L. Fox, Trans.) Bronx: Gjonlekaj Publishing Co.

Gower, M. (2013). Revenge: Interplay of Creative and Destructive Forces. Clinical Social Work Journal, 41(1), 112-118. Retrieved from http://download.springer.com.argo.library.okstate.edu/static/pdf/82/art\%253A10.1007\%252Fs10615-012-0407-

0.pdf?auth66=1399163270_7dadec095480dec997562b8ffe8c8445\&ext=.pdf

Grutzplak, J. (2002). Blood Feud and Modernity: Max Weber's and Emile Durkheim's Theories.

Journal of Classical Sociology, 2(2), 115-134. Retrieved from http://content.ebscohost.com/pdf18_21/pdf/2006/GG1/01May06/ 21783277.pdf?T=P\&P=AN\&K=21783277\&S=R\&D=aph\&EbscoContent=dGJyMNLe80Sepq84y9ł3OLCmrOyep7VSrqq4SrWWxW XS\&ContentCustomer=dGJyMPGnr1CvqbNluePfgeyx33vf2uOF59kA

Hanbury-Tenison, R. (2009). Riding through Europe's forgotten country. London: I.B. Tauris. Retrieved from http://site.ebrary.com.argo. library.okstate.edu/lib/okstate/docDetail.action?doclD=10377907

Holmes, L. (2009). Communism: A very short introduction. Cary: Oxford University.

Hupchick, D. P., \& Cox, H. E. (2001). From Constantinople to Communism. New York: Palgrave Macmillan.

Johnson, R. (2002, December 14). Is Revenge At The Heart Of Bush's Iraq Policy? Some Question Whether Unfinished Family Business Motivates The President's Anti-saddam Sentiment. Orlando Sentinel, pp. 1-2. Retrieved from http://articles. orlandosentinel.com/2002-12-14/news/0212130465_1_revenge-bush-family-business

Jones, C. (2010). Human rights and moral cosmopolitanism. Critical Review of International Social and Political Philosophy, 13(1), 115135.

Lerch, M. (2013). Patriarchy and fertility in Albania. Demographic Research, 29, 133-165. Retrieved from http://media.proquest.com. argo.library.okstate.edu/media/pq/classic/doc/3227166161/fmt/pi/rep/NONE?hl=\&cit\%3Aauth=Lerch\%2C+Mathias\&cit\%3Atitle=P atriarchy+and+fertility+in+Albania\&cit\%3Apub=Demographic+Research\&cit\%3Avol=29\&cit\%3Aiss=\&cit\%3Apg=133\&cit\%3Ada

Littlewood, R. (2002). Trauma and the Kanun: Two Responses to Loss in Albania and Kosova. International Journal of Social Psychiatry, 48(2), 86-96. Retrieved from http://isp.sagepub.com/content/48/2/86.full.pdf+html 
Malcolm, N. (1998). Kosovo: A Short History. New York: New York University Press.

McClear, S. A. (2001). Albanians and their culture: A study of their defining character and uniqueness. (Order No. 1409458, California State University, Dominguez Hills). ProQuest Dissertations and Theses, , 117-117 p. Retrieved from http://search.proquest.com/ docview/230809213?accountid=4117. (230809213).

Memushi, L. (2003). Reformimi i Shkolles, proces dhe strategji. Tirane: Dituria.

Messner, S. F., \& Rosenfeld, R. (2001). Crime and the American Dream. Belmont: Wadsworth.

Nees, Scott, "Pogg'es Institutional Cosmopolitanism." Thesis, Georgia State University, 2010. http://scholarworks.gsu.edu/philosophy_ theses/69

Oxford English Dictionary Online. (2014, March). vendetta, n. Oxford University Press. Retrieved May 2, 2014, from http://www. oed.com/view/Entry/222061?redirectedFrom=vendetta\#eid

Pettifer, J. (1994). Blue Guide: Albania. New York: WW Norton.

Picker, R. C. (1997). Games in a Complex World: A Generative Approach to the Adoption of

Norms. The University of Chicago Law Review, 64(4), 1225-1288. Retrieved from http://www.jstor.org/stable/1600216

Rainer, P. (2012, February 24). THe Forgiveness of Blood: movie review. The Christian Science Monitor. Retrieved from http://argo.library.okstate.edu/login?url=http://search.proquest.com.argo.library.okstate.edu/docview/923300554?accountid=4117

Rieff, D. (1997). Homelands: Albania. Salmagundi(116/117), 19-31. Retrieved from http://search.proquest.com/docview/ 221311622/fulltextPDF?accountid=4117

Saltmarshe, D. (1999). Identity in a post-communist balkan state: A study in north Albania.

(Order No. U601853, University of Bath (United Kingdom)). PQDT - Europe, Retrieved from http://search.proquest.com/docview/ 1465065235?accountid=4117. (1465065235).

Schmidt-Neke, M. (2007). Albania. In W. Horner, H. Dobert, B. VonKopp, \& W. Mitter, The Education Systems of Europe (pp. 11-31). Dordrecht: Springer. Retrieved from http://ud4cl8nx8h.search.serialssolutions.com/?ctx_ver=Z39.88-2004\&ctx_enc=info\%3 Aofi\%2Fenc\%3AUTF-8\&rf__id=info:sid/summon.serialssolutions.com\&rft_val_fmt=info:ofi/fmt:kev:mtx: book\&rft.genre=book\%20item\&rft.title=The+Education+Systems+of+Europe\& \&rt.atitl

Schwandner, S. (1996). Albanians. In Encyclopedia of World Cultures (Vol. 4, pp. [3]-8). New York: Macmillan Reference USA. Retrieved from http://go.galegroup.com/ps/i.do?id=GALE\%7CCX3458000612\&v=2.1\&u=stil74078\&it=r\&p=GVRL\&SW=w\& asid $=8 \mathrm{a} 5 \mathrm{~d} 923 \mathrm{cc} 39 \mathrm{~b} 6 \mathrm{efd} 1 \mathrm{cbf9f5d50acdc01}$

Schwegler, U., \& Smith, L. R. (2012). Ethno-political Conflict in Kosovo: Cultivating Trust in Serbian-Albanian Post-conflict Peace building. In D. Landis, \& R. D. Albert, Handbook of Ethnic Conflict: International Perspectives (pp. 349-378). Hilo, Hawaii, United States of America: Springer Science+Business Media, LLC. Retrieved from http://download.springer.com/static/pdf/300/bok\% 253A978-1-4614-0448-4.pdf?auth66=1399225064_251b23d27794d2b70afc26b303aaf001\&ext=.pdf

Sommers, T. (2009). The two faces of revenge: moral responsibility and the culture of honor. Biology \& Philosophy, 24(1), 35-50. Retrieved from http://download.springer.com/static/pdf/585/art\%253A10.1007\%252Fs10539-008-9112-3.pdf?auth66=139922 6530_1515107f1676da4c656d2b335d96415a\&ext=.pdf

The Council of Europe. (2014). The Council of Europe in Brief - The Council of Europe. Retrieved May 1, 2014, from The Council of Europe: http://www.coe.int/aboutCoE/index.asp?page=nosObjectifs\&l=en

Thompson, T. (2003, May 25). The ethnic connection: Special investigation: Albanian pimps: Prostitution: Blood feuds behind vice killings. The Observer, p. 11.

Tokareva-Parker, K. (2004). Honor, justice, and revenge in feuding germanic society. (Order No. 3156326, Indiana University). ProQuest Dissertations and Theses, , 265-265 p. Retrieved from http://search.proquest.com/docview/ 305200989?accountid=4117. (305200989).

Triantafilou, E. E. (2005). In Aid of Transitional Justice: Eroding Norms of Revenge in Countries With Weak State Authority. 10 UCLA Journal of International Law \& Foreign Affairs, 541-561. Retrieved from www.lexisnexis.com/hottopics/lnacademic

UN General Assembly. (2014, May 1). The Universal Declaration of Human Rights. Retrieved from The Universal Declaration of Human Rights: http://www.un.org/en/documents/udhr/history.shtml

Valinas, M., \& Arsovska, J. (2008). A restorative approach for dealing with the Kosovo conflict. In I. Aertsen, H.-C. R. Jane Arsovka, M. Valinas, \& K. Vanspauwen, Restoring Justice after Large-Scale Violent Conflicts (pp. 183-213). Portland/Cullompton: Willan Publishing.

Waldmann, P. (2001). Revenge Without Rules: On the Renaissance of an Archaic Motif of Violence. Studies in Confict \& Terrorism, 24(6), 435-450. Retrieved from http://ud4cl8nx8h.search.serialssolutions.com/?ctx_ver=Z39.88-2004\&ctx_enc=info\% 3Aofi\% 2Fenc\%3AUTF-8\&rff_id=info:sid/summon.serialssolutions.com\&rft_val_fmt=info:ofi/fmt:kev:mtx:journal\&rft.genre=article\&rft.atitle $=$ Revenge+without+rules\%3A+On+the+renaissan

Young, A. (2000). Women who become men: Albanian sworn virgins. Oxford, New York, United Kingdom, United States of America: Berg

Zickel, R., \& Iwaskiw, W. (1992, April). A Country Study: Albania. Retrieved 05 01, 2014, from Federal Research Division, Library of Congress: http:///cweb2.loc.gov/frd/cs/altoc.htm/\#al0000 